\title{
EXTERNAL AUDITORY CANAL CHOLESTEATOMA EVOLVING FROM KERATOSIS OBTURANS: A MYTH OR REALITY
}

Arivazhakan Ganesh Bala1, George Tukalan², Alagappan Kannapan³, Jalagandeesh Balachandran4, Rizwan Rafeeque ${ }^{5}$

${ }^{1}$ Assistant Professor, Department of ENT, Vinayaka Mission Medical College, Karaikal.

${ }^{2}$ Final Year Post Graduate Student, Department of ENT, Vinayaka Mission Medical College, Karaikal.

${ }^{3}$ Final Year Post Graduate Student, Department of ENT, Vinayaka Mission Medical College, Karaikal.

${ }^{4}$ Final Year Post Graduate Student, Department of ENT, Vinayaka Mission Medical College, Karaikal.

${ }^{5}$ First Year Post Graduate Student, Department of ENT, Vinayaka Mission Medical College, Karaikal.

ABSTRACT

AIM

To describe that External Auditory Canal Cholesteatoma (EACC) can evolve from long standing cases of Keratosis Obturans (KO).

\section{MATERIALS AND METHODS}

Total of 5 patients was examined and clinically diagnosed to have keratosis obturans. Three patients out of this had previous history of keratosis obturans in the EAC which was removed 2 years back in our hospital. All the patients were posted for removal of keratosis obturans under general anaesthesia. The removed specimen was sent for histopathological examination.

\section{RESULTS}

The five patients had whitish debris filling the external auditory canal in the background of inflammation. In all the cases there was widening of external auditory canal with inflammation. In two cases there was erosion of bony external auditory canal.

\section{CONCLUSIONS}

The clinical picture of EACC and KO is overlapping to a certain extent, but KO is more common than EACC. EACC is usually seen to arise in long term and neglected cases of KO.

\section{KEYWORDS}

Keratosis Obturans, External Auditory Canal Cholesteatoma, Ear Wax, Ear Ache.

HOW TO CITE THIS ARTICLE: Bala AG, Tukalan G, Kannapan A, et al. "External auditory canal cholesteatoma evolving from keratosis obturans: A myth or reality." Journal of Evolution of Medical and Dental Sciences 2015; Vol. 4, Issue 105, December 31; Page: 17088-17091, DOI: 10.14260/jemds/2015/2591

\section{INTRODUCTION}

Keratosis Obturans (KO) is the accumulation of desquamated keratin appearing as large plug in the external auditory canal. It probably results from faulty migration of squamous epithelial cells which arise from the outer surface of tympanic membrane and from the skin of the adjacent part of bony external auditory canal, which becomes mixed with ear wax to form a thick plug. Keratosis obturans is usually bilateral and frequently associated with bronchiectasis and sinusitis in younger patients.[1] Pathologically keratosis obturans seems to be a compact plug of keratin debris bound with hyperplasia of underlying epithelium and chronic inflammation of subepithelial tissue. It can lead to ballooning of external auditory canal which may even cause smooth erosion of bony canal rarely affecting the deeper structures. External Auditory Canal Cholesteatoma (EACC) occurs as a consequence of invasion of squamous tissue in the external auditory canal into a localised area of bony erosion in a background of periostitis in canal wall.

Financial or Other, Competing Interest: None.

Submission 16-11-2015, Peer Review 17-11-2015,

Acceptance 26-12-2015, Published 31-12-2015.

Corresponding Author:

Dr. Arivazhakan Ganesh Bala,

No-5, K. Sellammal Illam,

Vallalar Street, P. K. Salai,

Karaikal-609602,

Puducherry.

E-mail: gbala.mbbs@gmail.com

DOI:10.14260/jemds/2015/2591
Both entities have overlapping features and require differentiation. ${ }^{[2]}$ We describe here five cases of keratosis obturans of varying severity from simple to complicated ones.

\section{MATERIALS AND METHODS}

Five patients were clinically examined and diagnosed to have keratosis obturans provisionally. Three patients out of this had previous history of keratosis obturans in the EAC which was removed in our hospital. All the patients were posted for removal under general anaesthesia. The removed specimens were sent for histopathological examination.

\section{Case 1}

A 22-year-old female presented to our OPD with pain and hard of hearing in the left ear since 1 month. After a detailed history taking clinical examination was done which revealed whitish debris filling the left external auditory canal. An attempt was made to remove the debris but was unsuccessful due to severe pain, thus removal was done under general anaesthesia. Intra operative examination revealed the skin of the EAC to be inflamed with apparent widening of the canal; the tympanic membrane appeared to be retracted and congested but intact. The removed specimen was sent for histopathological examination which was reported as keratosis obturans.

\section{Case 2}

A 32-year-old male presented to our OPD with hard of hearing and foul smelling discharge, itching and tinnitus from right ear since 1 year. 
Detailed history taking revealed that he had similar symptoms 3 years back for which he had consulted our department and was diagnosed as keratosis obturans for which removal was done. Clinical examination revealed whitish debris filling the right EAC. This patient was also considered for removal under general anaesthesia. Intraoperative examination showed inflammation with widening of the canal. The tympanic membrane was congested and retracted without perforation. The removed specimen was sent for histopathological examination, which revealed that it was EACC.

\section{Case 3}

A 17-year-old girl presented to our OPD with ear discharge, itching and pain in the right ear since 3 weeks. After history taking, clinical examination showed whitish debris filling the right EAC. The patient was posted for removal under general anaesthesia. The EAC appeared inflamed and ballooned intraoperatively with an intact tympanic membrane. The removed specimen was sent for histopathological examination which gave a diagnosis of keratosis obturans.

\section{Case 4}

A 42-year-old female presented to our OPD with blocking sensation, hard of hearing, pain, itching and foul smelling discharge in the left ear since 4 months. She had a history of similar complaints in the past which was about 4 years back and was diagnosed as keratosis obturans for which removal was done. Clinical examination revealed whitish debris filling the EAC. Removal was done under general anaesthesia. Intraoperative examination showed that the external auditory canal was widened in the background of inflammation with an intact tympanic membrane. Histopathological examination was suggestive of EACC.

\section{Case 5}

A 30-year-old male presented to our OPD with pain, hard of hearing, tinnitus and blocking sensation on the right ear since two months. A detailed history was taken which revealed similar complaints in the past and diagnosed as keratosis obturans which was removed 2 years back. Further clinical examination revealed whitish debris filling the EAC for which removal was done under general anaesthesia. The external auditory canal was widened with signs of inflammation. The tympanic membrane appeared to be lustreless but intact. The specimen was sent for histopathological study which was suggestive of keratosis obturans.

In two patients with EACC, there were signs of erosion of bony external auditory canal in CT scan

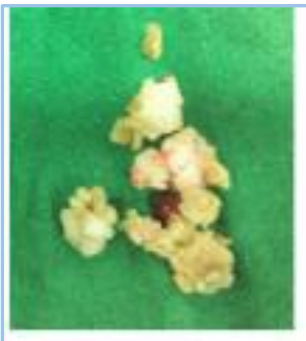

Fig. 1: Removed Keratosis obturans

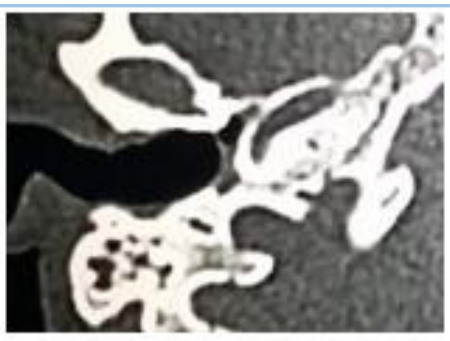

Fig. 2: CT Temporal bone of showing ballooning of left EAC

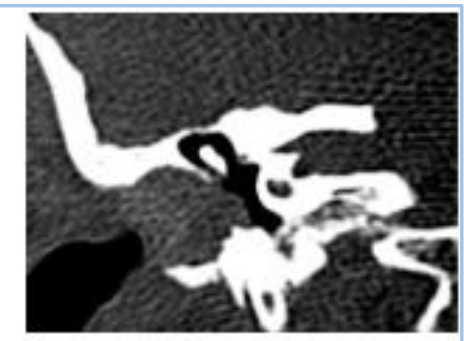

Fig. 3: CT temporal bone showing erosion of left EAC

\section{DISCUSSION}

Keratosis obturans and external auditory canal cholesteatoma are distinct clinical and pathological entities. In the 1980s, they were defined as separate entities.[2],[3] In keratosis obturans the keratin plug seen in the ballooned external auditory canal is quite geometrically patterned. The keratin squames that are shed from the perimeter of the deep ear canal forms a laminar arrangement. In External auditory canal cholesteatoma, the keratin mass is primarily derived from a sac that involves the bony external auditory canal where random keratin is seen in the lumen of the ear canal. It is proposed that there are two types of keratosis obturans. The first one is inflammatory in nature and occurs secondary to an acute condition, such as a viral infection leading to inflammation of the ear canal which alters the normal epithelial migration temporarily and can be restored by removal of the keratin plug from the canal. The second type also known as the silent type is a continuing disease and is caused by unusual separation of the keratin that remains even after the initial removal and may require successive removals. ${ }^{[4]}$

The exact aetiology of external auditory canal cholesteatoma is obscure. In some cases external auditory canal cholesteatoma is post-traumatic or postsurgical, for example in surgeries like stapedectomy.
It is hypothesized that a portion of bare bone of the external auditory canal becomes infected and sequests leading to migration of epithelium into the bony abnormality to form cholesteatoma. It is also suggested that osteitis and invasion of epithelium were secondary to inflammatory changes of the skin.[5] The frequency of external auditory canal cholesteatoma is about 1 in 1000 new cases in otology and for every case of external auditory canal cholesteatoma there are 4 to 5 cases of keratosis obturans.[6] Keratosis obturans is more common than external auditory canal cholesteatoma.[7] It is seen that KO more commonly occurs in younger patients while external auditory canal cholesteatoma is more common in elderly patients. Acute severe otalgia and conductive hearing loss are the classical presenting symptoms of keratosis obturans.

A different set of clinical findings are seen in external auditory canal cholesteatoma, which includes chronic otorrhea, dull pain and itching in the ear associated with minimal hearing loss. Initial investigation for KO and EACC is microscopic ear examination. Ear canal becomes ballooned or grossly widened in keratosis obturans and can even lead to automastoidectomy. To assess bony widening or erosion, computed tomography of temporal bone is essential.

The differential diagnosis of both these conditions includes carcinoma of the ear canal, necrotizing otitis externa 
and benign bony sequestration $\mathrm{n}$ the external auditory canal. This makes it mandatory to conduct a histopathological examination of the granulation tissue from the external auditory canal to rule out malignancy. Due to severe pain and hearing loss in keratosis obturans, it needs to be removed under general anaesthesia and requires regular aural toileting to prevent recurrence. Canalplasty can be attempted in recurrent cases of keratosis obturans with promising results. ${ }^{[8]}$ In case of external auditory canal cholesteatoma where the extent cannot be visualised, surgical excision of necrotic bone and cholesteatoma through the mastoid is done and the resultant defect is repaired using temporalis fascia graft. ${ }^{[8]}$ The other surgical procedure that can be employed is canal-wall-up mastoidectomy with repair of the defect.

\section{RESULTS}

The five patients had whitish debris filling the external auditory canal in the background of inflammation. Out of the five patients there were three females and two males. In all the cases there was widening of external auditory canal with inflammation. Three out of the five cases had past history of diagnosed keratosis obturans which was surgically removed. The right ear was affected in three cases and the left ear in two cases. Patients with KO had ballooning of the EAC while bony erosions were seen in two cases. The details are shown in Tables 1, 2 and 3.

\begin{tabular}{|c|c|c|c|c|}
\hline Case & Clinical Presentation & Side & Age & Sex \\
\hline 1 & Pain, Hard of hearing & Left & 22 & $\mathrm{~F}$ \\
\hline 2 & $\begin{array}{c}\text { Hard of hearing, Discharge, } \\
\text { Tinnitus, Itching }\end{array}$ & Right & 32 & $\mathrm{M}$ \\
\hline 3 & Discharge, Pain, Itching & Right & 17 & $\mathrm{~F}$ \\
\hline 4 & $\begin{array}{c}\text { Blocking sensation, Hard of } \\
\text { hearing, Pain, Discharge, } \\
\text { Itching }\end{array}$ & Left & 42 & $\mathrm{~F}$ \\
\hline 5 & $\begin{array}{c}\text { Pain, Hard of hearing, } \\
\text { Blocking sensation, Tinnitus }\end{array}$ & Right & 30 & $\mathrm{M}$ \\
\hline \multicolumn{4}{|c|}{ Table 1 } \\
\hline
\end{tabular}
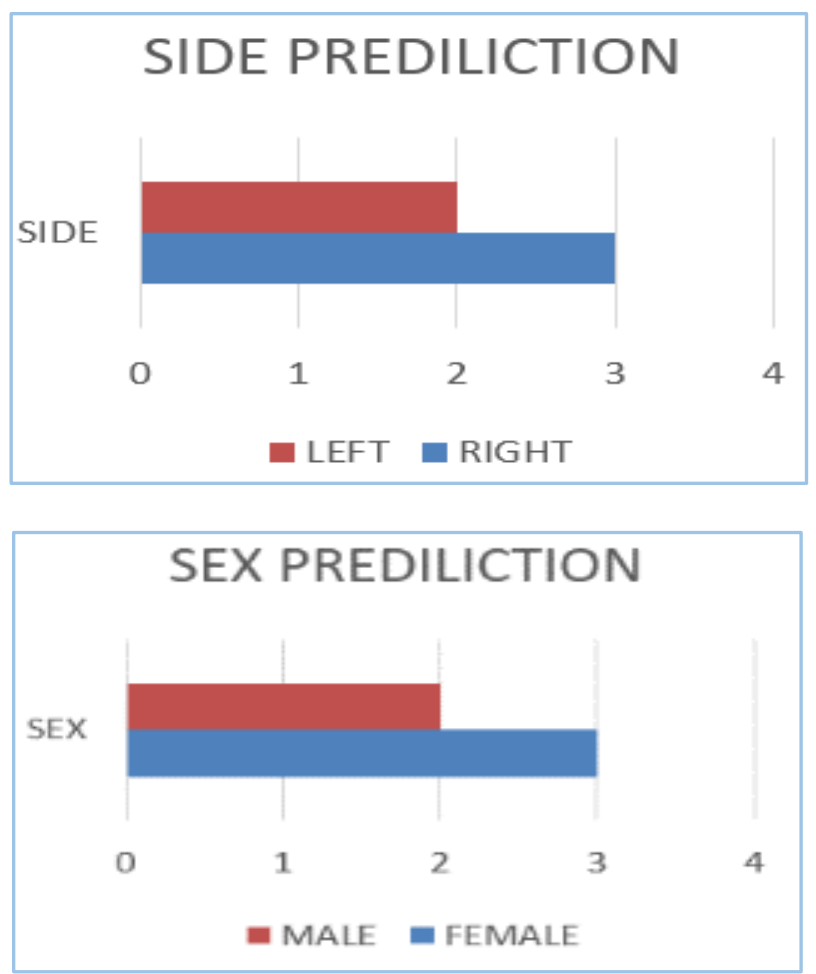

\begin{tabular}{|c|c|c|}
\hline $\begin{array}{c}\text { Sl. } \\
\text { No. }\end{array}$ & Ear Symptoms & $\begin{array}{c}\text { No. of } \\
\text { Patients }\end{array}$ \\
\hline 1 & Ear Pain & 4 \\
\hline 2 & Ear Discharge & 3 \\
\hline 3 & Hard of Hearing & 4 \\
\hline 4 & Ear itching & 3 \\
\hline 5 & Ear blockade & 5 \\
\hline 6 & Tinnitus & 2 \\
\hline 7 & Giddiness & - \\
\hline 8 & Facial weakness & - \\
\hline \multicolumn{3}{|c|}{ Table 2 } \\
\hline
\end{tabular}

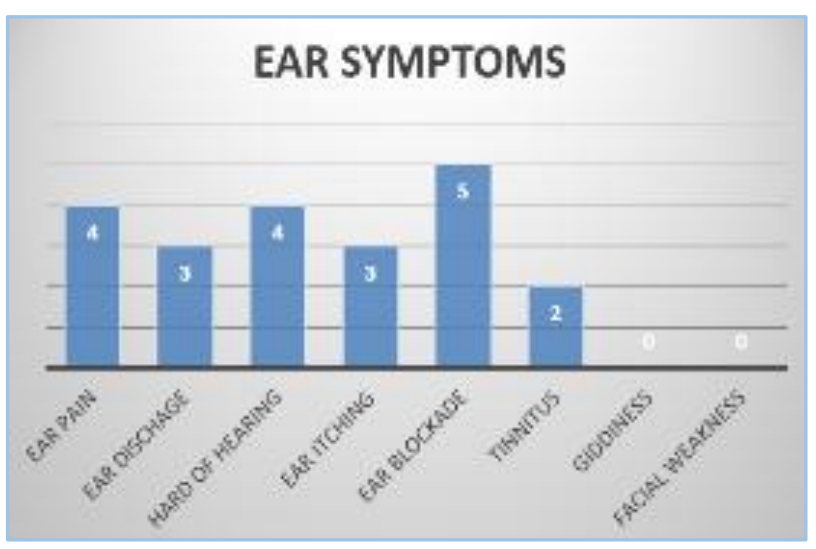

\begin{tabular}{|c|c|c|}
\hline Case & CT Temporal Bone Findings & Histopathology \\
\hline 1 & Ballooning & KO \\
\hline 2 & Erosion of EAC & EACC \\
\hline 3 & Ballooning & KO \\
\hline 4 & Erosion of EAC & EACC \\
\hline 5 & Ballooning & KO \\
\hline \multicolumn{2}{|c|}{ Table 3 } \\
\hline
\end{tabular}

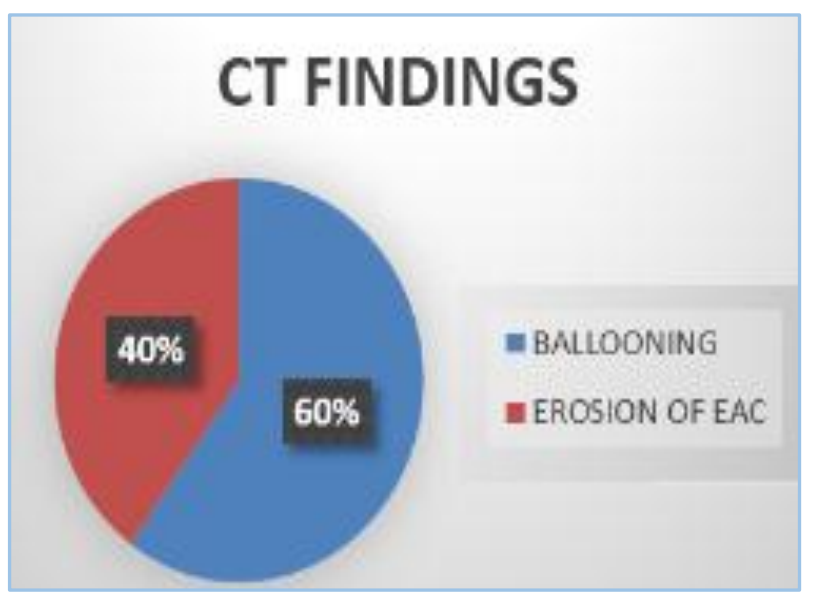

\section{CONCLUSION}

Keratosis is not a very common entity and principally arises from desquamative process in the ear canal. The clinical picture of External auditory canal cholesteatoma and Keratosis obturans is overlapping to a certain extent but $\mathrm{KO}$ is more common than EACC. EACC is usually seen to arise in long term and neglected cases of KO. Patients with KO should be closely monitored with regular followup. 


\section{REFERENCES}

1. Marta E Heilbrun, Karen L Salzman, Christine M Glastonbury, H Ric Harnsberger, Richard J Kennedy and Clough Shelton: External auditory canal cholesteatoma: clinical and imaging spectrum. AJNR Am J Neuroradiol 24:751-756, April 2003.

2. Piepergerdes MC, Kramer BM, Behnke EE: Keratosis obturans and external auditory canal cholesteatoma; Laryngoscope 1980 Mar; 90:383-91.

3. Shire JR, Donegan JO. Cholesteatoma of the external auditory canal and keratosis obturans. American Journal of Otology. 1986; 7:361-4.

4. Hawke M, Shanker L. Automastoidectomy caused by keratosis obturans: A case report. Journal of Otolaryngology. 1986;15:348-50.
5. Hanne H Owen, Jørn Rosborg and Michael Gaihede. Cholesteatoma of the external ear canal: etiological factors, symptoms and clinical findings in a series of 48 cases. BMC Ear, Nose and Throat Disorders 2006, 6:16.

6. Anthony PF, Anthony WP. Surgical treatment of external auditory canal cholesteatoma. Laryngoscope. 1982;92:705.

7. Sharma RC. Is Keratosis obturans a predisposing factor for external auditory canal cholesteatoma: Some interesting cases. Indian J Otol 2014;20:99-101.

8. Paparella MM, Goycoolea MV. Canalplasty for chronic intractable external otitis and keratosis obturans Otolaryngology, Head and Neck Surgery. 1981;89:440-3. 